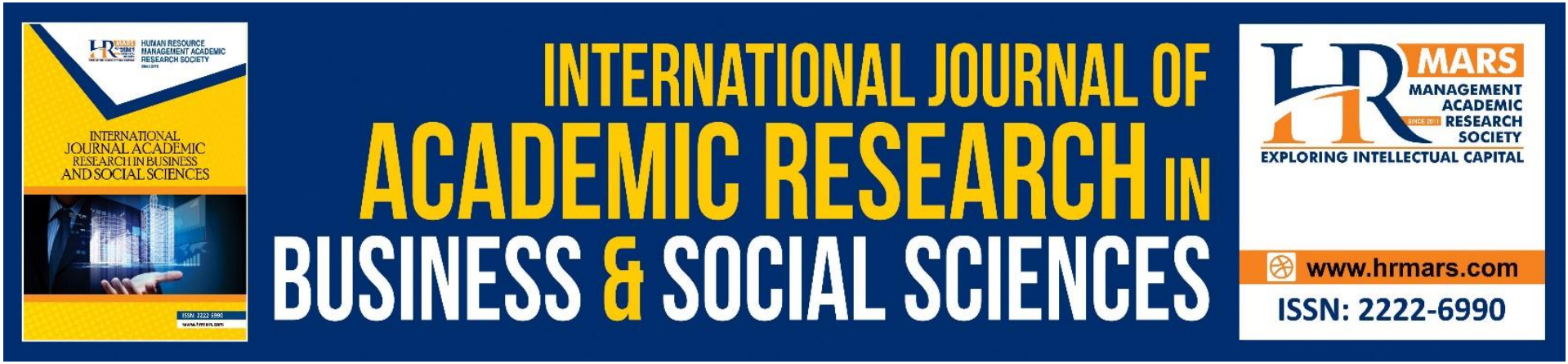

\title{
A Need Analysis of Kadimel Module for the Malay Vocabulary Learning among Vocational College Students in Malaysia
}

Thibbah A/P Gatanagayan, Fadzilah bte Amzah

To Link this Article: http://dx.doi.org/10.6007/IJARBSS/v11-i11/11572

DOI:10.6007/IJARBSS/v11-i11/11572

Received: 10 September 2021, Revised: 13 October 2021, Accepted: 26 October 2021

Published Online: 14 November 2021

In-Text Citation: (Gatanagayan \& Amzah, 2021)

To Cite this Article: Gatanagayan, T. A., \& Amzah, F. bte. (2021). A Need Analysis of Kadimel Module for the Malay Vocabulary Learning among Vocational College Students in Malaysia. International Journal of Academic Research in Business and Social Sciences, 11(11), 842-861.

Copyright: (c) 2021 The Author(s)

Published by Human Resource Management Academic Research Society (www.hrmars.com)

This article is published under the Creative Commons Attribution (CC BY 4.0) license. Anyone may reproduce, distribute, translate and create derivative works of this article (for both commercial and non-commercial purposes), subject to full attribution to the original publication and authors. The full terms of this license may be seen

at: http://creativecommons.org/licences/by/4.0/legalcode

$$
\text { Vol. 11, No. 11, 2021, Pg. } 842-861
$$

Full Terms \& Conditions of access and use can be found at http://hrmars.com/index.php/pages/detail/publication-ethics 


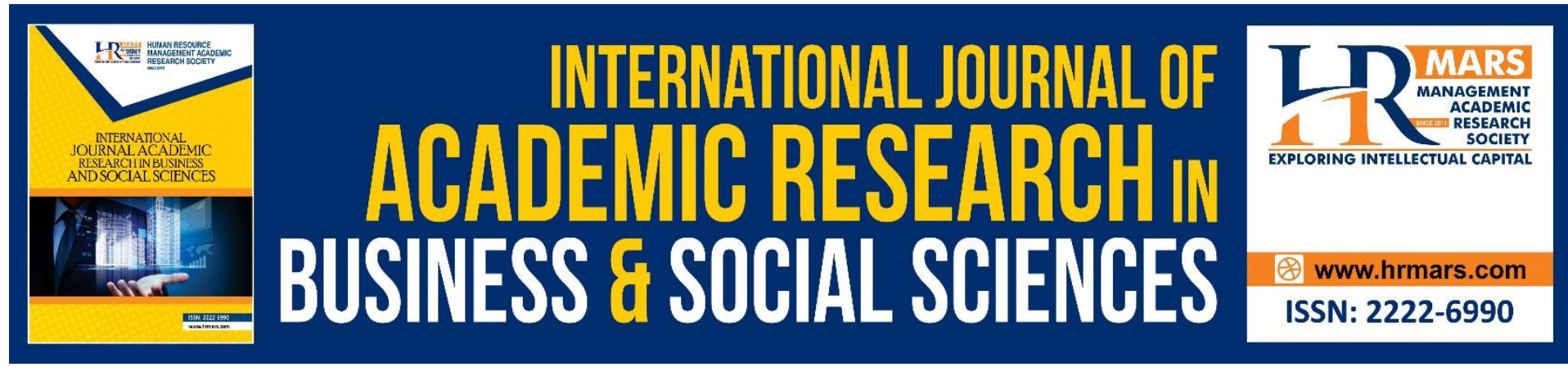

\title{
A Need Analysis of Kadimel Module for the Malay Vocabulary Learning among Vocational College Students in Malaysia
}

\author{
Thibbah A/P Gatanagayan¹, Fadzilah bte Amzah² \\ ${ }^{1}$ Kolej Vokasional Balik Pulau, ${ }^{2}$ Universiti Sains Malaysia \\ Email: thibbah84@student.usm.my,fadzilahamzah@usm.my
}

\begin{abstract}
Vocabulary is an essential aspect of Malay Language learning. According to Wilkins (1922), without grammar very little can be conveyed, without vocabulary nothing can be conveyed. Hence, it is important for teachers to emphasis on the most effective way to aid the students in vocabulary learning and acquisition. The advancement of technology has opened a new door for language learning providers and instructors to teach vocabulary for language learners using online technological interventions, such as the Quizlet applications. Yet, little studies in the literature focused on the design and development of online tools in the delivery of Malay Language subject, particularly on the vocabulary aspect, for vocational students in this country. This needs analysis study aimed to firstly understand the current practices and emerging issues in the teaching and facilitation of Malay Language subject in vocational colleges in Malaysia. Then, it sought to identify the needs in developing a specific vocabulary module of Malay language subject for vocational students, namely the Kadimel module. The multi-method research was employed, i.e through survey and quiz involving teachers and students from different vocational colleges in this country, in order to to gather both quantitative and qualitative inputs for identifying the students' and teachers' needs in developing the Malay vocabulary learning module. Findings revealed that although there are a variety of printed teaching resources and materials available for the Malay Language subject, there are certain issues and problems throughout the teaching and facilitation of the subject to the vocational students, including the lack of uniformity in the use of the resources. Furthermore, there are also issues related to the students' learning aspects, such as difficulties in vocabulary learning, low motivation in learning grammatical aspect, and lack of understanding and poor quiz achievement in the usage and writing skills for vocabulary aspects. Further findings outlined that the requirements for developing the Malay language vocabulary learning module include learning reinforcement, interactive and collaborative learning, simple, flexible, and effective content, as well as uniformity of references and content.
\end{abstract}

Keyword: Vocational Students, Malay Language, Vocabulary Module, Quizlet, Needs Analysis. 


\section{Introduction}

The Malay language has undeniably established a strong position as the main language of communication and instruction in Malaysian education system. Nowadays, it is widely used as the medium for teaching and learning process in many educational institutions, as well as private sector and even in other institutions overseas, particularly in Southeast Asian region. In school setting, Malay serves as the official language of instruction in most public schools in Malaysia, while English is studied as a foreign language at all levels of education (Clayton, 2006). Although English is still considerably the dominant language in the trade and industrial sectors in this country, Article 152 of the federal constitution explains that Bahasa Melayu (Malay language), which is also known as Bahasa Malaysia, is the official language that cannot be disputed on its functions and role as the national language of Malaysia (MyGovernment, 2019). The implementation of Science, Technology, Engineering, and Mathematics (STEM) education in primary and secondary schools still emphasizes on the importance and relevance of the Malay language in assisting students to gain more understandings on the meaning of each word, term, and its usage in STEM (Aminudin, 2018).

In higher education setting, although English is widely used in teaching and learning process, the Malay language still plays a key role as the "bridge" connecting students' understanding in English-based notes and course materials (Anida \& Faredza, 2017). The Ministry of Education Malaysia (MOE) has embarked various initiatives to raise the status and role of the Malay language, and one of such initiatives was a collaborative study in 2010 between the ministry and researchers from various Higher Education Institutions (HEIs) on "The Use of Language in Public HEls" (Khuzaiton \& Thana, 2014). Based on the study findings, the ministry then set up the Action Plan for Upholding the Malay Language as the Language Sciences at the HEls (Khuzaiton \& Thana, 2014). One of the three strategies in the action plan is where the Malay language is introduced to foreign students as a compulsory subject for them in undertaking various courses at the HEls (Abd. Manan et al., 2010; Khuzaiton \& Thana, 2014).

Like other schools in this country, Malay language is delivered as one of the core subjects in the course syllabus in vocational colleges. Vocational colleges, which are under the MOE provide educational opportunities for students who have undertaken PT3 assesment in secondary schools to obtain diploma in technical, vocational, or skills training after four years of study. The syllabus of Malay Language subject for vocational colleges, or more accurately known as Curriculum Standard Document of Vocational College (DSK) outlines five competencies to be mastered by the students, namely: (i) the interpersonal communication competency which involves conversation aiming to establish connection with others, to present thoughtful opinions, and to negotiate towards certain consensus; (ii) competency in obtaining, processing, and conveying information; (iii) competency in producing creative and non-creative writings; (iv) competency in literary appreciation by focusing on the genres of traditional poetry, short stories and dramas; and ( $v$ ) the competency of language system applications (MOE, 2012).

Like other subjects, one of most common teaching and learning mode of the Malay language subject in schools and educational institutions, including vocational colleges, is text-book method. With the current technological advancement in educational process nowadays, the conventional text-book method and face-to-face approach of language teaching and learning is also utilized in line with other blended learning approach, i.e. the use of technological and 
ICT tools, such as online and multimedia applications. Firdaus et al. (2013) mentioned that technology has benefited both students and teachers as they are able to learn language in an interactive manner, not limited to only classroom but it is accessible anywhere and at any time.

With regards to the language components, vocabulary is one of essential aspects of Malay language learning. According to Wilkins (1922), without grammar very little can be conveyed, and without vocabulary nothing can be conveyed. It is important for teachers to emphasis on the most effective way to aid the students in vocabulary learning and acquisition. Therefore, it is of vital importance for language learning providers and instructors to diversify their approach in delivering the vocabulary lessons. This is as supported by Shanmugam, Guat, \& Nadarajan (2015) who stressed on the importance for teachers to expose students to Malay vocabulary learning from a variety of sources because these activities and processes can help them to construct information and ideas effectively, diversify the vocabulary usage, and express higher level of thinking.

In light of current learning needs and language abilities of Malay language among students in vocational colleges, this study proposed the development of a web-based vocabulary module for the Malay language subject, namely the Kadimel module, for vocational college students in Malaysia as one of pedagogical tools to support their current mode of the language learning. Quizlet is seen as a potential platform for the development of the module. It is a flashcard-like system, freely available in computer software and mobile platforms, which allows teachers to choose from a wide range of existing vocabulary sets in a range of different languages as well as creating their own activities. With its online accessibility and benefits, Quizlet was found to be an effective online teaching-learning support for language learning, not only because it is more interesting for students, but it is also capable of providing multiple functions at one time to support students' self-learning process (Zaki et al., 2014).

\section{Problem Statement}

The teaching and learning of Malay language in Malaysian has been given much emphasis in the literature, such as in public schools (Abdul Rasid, 2011; Loh \& Zahnatun, 2019; Zulkifli, 2013) and higher education institutions (Celinea et al., 2009; Juwairiah et al., 2018). On the other hand, not much focus are given specifically on the teaching and learning of Malay Language in vocational colleges in Malaysia. However, from a more general view, some studies did report on several pedagogical and learning issues related to the vocational education setting in this country, such as the moderate level of 21st century teaching skills among vocational teachers (Mariani et al., 2014), as well as student attitude, time constraint, limited exposure or lack of training, extra effort from the teachers, and teacher burden (Sanitah et al., 2017).

Despite the above, one possible challenge in the delivery of Malay language subject in vocational colleges is limited technical-based resources for Malay language subject, particularly on specific technical-related context. Presently, one of the main resources available for the vocational students to learn the Malay language syllabus are textbooks which are not designed to cater to their technical needs and language abilities in the vocational syllabus. According to Kamisah et al (2016), most technical courses, especially engineeringrelated, are usually carried out in English, thus the students have little exposure to technical terminology in Malay Language. Furthermore, a study by Zamri et al (2011) reported that the 
Malay Language teachers had moderate level of attitude toward the use of text books, particularly in terms of content, presentation as well as activities and practice. The available textbooks are also criticized for not allocating sufficient place to collocations. According to Tsai (2015, as cited in Nurmukhamedov, 2016), collocations are disregarded in the coursebooks, or often presented out of context. Similarly, Kilickaya and Krajka (2010) explained, despite the availability of a large number of practical books, teachers still mostly rely on traditional ways, especially to teach vocabulary.

Another issue related to pedagogical aspect is in terms of limited technological tools to support Malay language teaching and learning in vocational colleges. A study by Zakaria (2014) revealed that Malay language teachers in eight vocational schools in Malaysia were having problems in using innovation in teaching and learning of Malay language subject. In addition, in the current educational scenario in this country, many teachers at schools are still practicing the memorization method in teaching and facilitating Malay language subject (Lai, 1017). According to Kilickaya and Krajka (2010), language teachers should enrich their teaching practice by using a variety of resources and tools so that the language learning process will be effective. This is due to the fact that the face-to-face approach and printed textbook method in the delivery of language education may present barriers to students' learning process, especially for today's generation who would require more dynamics in learning.

In terms of learning aspect, one of emerging issues among Malaysian students nowadays is regarding their poor skills and abilities in learning certain areas of Malay language, especially in grasping the vocabulary aspect of the language. As reported by Kamisah et al. (2016), vocabulary is one of the language aspects which technical students in Malaysia are having difficulties with. Similarly, Zahratulnadirah (2012, as cited in Loh \& Zahnatun, 2019) identified that students' poor writing skills in Malay language is caused by their limited vocabulary skills. Although the Malay language seems to be easier to master and be spoken due to its main use in this country, the fact is that many people, especially students, still fail to use it by following the real standard of the language (Hanisah, 2016). Like any other language, the acquisition of vocabulary knowledge in Malay language education is viewed as one important step in gaining necessary level of understanding on certain subjects being taught. This is particularly challenging for vocational students who have to learn various technical-related terms which are mostly available in English medium, and they have to adapt these understandings.

Moreover, low motivation in learning the Malay language among the students could be one of the hindering factor, especially when it comes effective delivery of the language subject at schools. Motivation has long been identified as one of the main factors affecting the process of learning languages (Gardner, 1985). As reported by Nagy (2007), the process of learning language, especially the vocabulary aspect, is a quite difficult process for students because it affects their level of motivation in language learning.

\section{Aim and Objectives of Study}

Considering the above issues on learning tools, resources, and students' motivation, there is a need to study the needs in designing a specific vocabulary module of the Malay language subject that suits the learning needs of vocational students in this country. Moreover, with the rapid technological development surrounding today's educational process, it seems 
necessary to develop an online-based tool to support existing classroom teaching and learning mode of the Malay language subject in vocational colleges.

The purpose of this study was to understand the current practices and emerging issues in the teaching and facilitation of Malay Language subject in vocational colleges in Malaysia, and thus to identify the needs in developing a specific vocabulary module of Malay language subject for vocational students.

Specifically, this study aimed to achieve the following research objectives:

1. To identify current teaching practices and resources of Malay Language subject in vocational colleges.

2. To evaluate the vocational students' learning and achievement in Malay Language subject.

3. To identify the emerging issues or challenges faced by the vocational teachers in the teaching and facilitation of Malay Language subject.

4. To outline the requirements for developing the module for Malay Language vocabulary learning for vocational students via the Quizlet applications.

\section{Literature Review}

\section{Development of Malay Language in Malaysia}

In this 21st century, the role of Malay Language has changed its context from an official language an official language, national language and language of knowledge to a language learned as a foreign language (Alias, et al., 2015). While not as widely needed as the English language, according to Sariyan (2006), the Malay language has set its own place among common languages of the world, especially among foreign language learners.

The Malay Language has a long historical development in this nation. After Malaya achieved its independence on August 31, 1957, the government sought to establish the language as the official national language of the country. During the time period, the government's efforts can clearly be observed in the administration field; a goal was set to be achieved after ten years of independence, that is all official affairs involving the writings of letters, trials in meetings, meeting minutes, and report preparation were made compulsory to be done in Malay language (Adam, 2013).

Education played an instrumental and influential role in the development and establishment of Malay as the national language and the official language of the Federation of Malaya. According to Adam (2013), the development of Malay as the country's national language in the educational aspect occurred between the period of 1957 to 1966, which was marked by two important documents that emphasized on the usage of Malay language as the language of instruction in all levels of education, i.e. the Razak's Report 1956 (Education Ordinance of 1957) and Abdul Rahman Talib's Report 1960.

Realizing the importance of English language proficiency among students and in response to the increasing globalization and technological advancement, the Malaysian government then introduced the Teaching and Learning of Science and Mathematics in English (PPSMI) policy in 2003 under the initiative of the then Prime Minister of Malaysia, Tun Dr. Mahathir Mohamad. The aim was to enable students to learn both subjects in its most significant lingua franca while preparing them as future workforce in the globalisation era and hence improving the human capital quality in Malaysia (Radzuwan, et al., 2016). The PPSMI policy was abolished by the Malaysian Cabinet in July 2009 and replaced with a new policy namely the Upholding the Malay Language and Strengthening Command of English (MBMMBI) policy which was officially introduced in 2012. The policy aimed to heighten students' proficiency 
and confidence in the use of both Malay and English languages, thus building a society that stands united, and thus producing competent citizens (MOE, 2014).

\section{Teaching and learning of the Malay Language Subject}

As the core compulsory subject in the school, the MOE has emphasized on the needs to establish appropriate teaching and learning materials and tools for the delivery of the Malay language subject in all schools, including vocational colleges. In fact, one of the objectives in the $\mathrm{MBMMBI}$ policy is to increase the infrastructure and support materials for the teaching and facilitation of both languages (MOE, 2014). However, in current education scenario in this country, many teachers in schools mainly practice memorization methods in their teaching techniques of the Malay language subject (Lai, 2017). A study by Faridah, et al (2014) similarly reported that teachers only have moderate level in applying the 21st century skills as one of their teaching strategies for most subjects in the vocational college. Therefore, Kilickaya and Krajka (2010) recommended language teachers to enrich their teaching practice with a variety of resources and tools for the language learning process to be effective.

As such, learning reinforcement is a vital process in education to ensure students can develop a long-term understanding of learned material. According to Kurzweil (2012), reinforcement is the process of reactivating memories and strengthening them during the process (Kurzweil, 2012). The traditional face-to-face classroom setting alone is not enough to help students retain their existing knowledge. Thus, there is a need to look into the aspect of reorganizing or perhaps to re-module the syllabus in vocational education to be more interactive for the students to engage themselves throughout the learning process.

\section{Vocabulary Learning of the Malay Language}

As outlined in the syllabus of Malay Language subject in the Integrated Secondary School Curriculum (MOE, 2015), vocabulary is an important component in Malay language system, apart from grammar, proverbs, spelling, as well as pronunciation and intonation. It consists of two parts, which are general vocabulary and terminologies (MOE, 2015).

Like most other languages, one needs to have a very strong foundation of the vocabulary knowledge in Malay language to enable them have accuracy in speech and writing to perform academic activities. The mastery of vocabulary has to be improved and developed so that students can express information and own ideas in conjunction with the increase of knowledge in other secondary school subjects (MOE, 2015). According to Tarigan (2011, as cited in Shanmugam et al., 2015), the level of language proficiency of an individual depends strongly on the quantity and quality of his or her vocabulary skills. Therefore, both language teachers and resources like textbooks and activity books should give more emphasis on the aspect of vocabulary mastery (Shanmugam et al., 2015).

\section{Quizlet as a Vocabulary Learning Tool}

Quizlet is a web-based platform which is one of the most widely used flashcard websites and has more than one million registered users and eighty million visitors and is a repository for over thirty million user-generated study sets (Quizlet, 2014). It is seen by many scholars and educational practitioners around the world as an excellent teacher-/student-friendly online vocabulary management system with an application and a website, catering for users seven powerful vocabulary learning tools for the creation of different vocabulary activities. 
The Quizlet applications include (Quizlet, 2014):

- Flashcards - For students to review the study set and listen to the pronunciation of the word or the phrase.

- Learn - For students to assess how well they know the definitions of the words and keeps track of what missing.

- Write - For students to measure their understanding and keep track of their learning progress.

- Spell - For student to type what they hear to improve spelling in this audiopowered study mode.

- Test $\quad-$ For students to practice based on different combinations of question types before a quiz or exam to assure they have thoroughly learned the terms.

- Match $\quad$-For students to match terms and definitions as quickly as possible.

- Gravity $\quad$-For students to practice learning through a fast-pace study game.

- Live -For students to engage in learning via game applications, either individually or in team.

Quizlet is seen as a potential platform for the development of a Malay language vocabulary learning module. In achieving the study objective, Quizlet was proposed as a tool for developing the Kadimel module for enhancing the learning of Malay vocabulary in vocational college environment.

\section{Methodology \\ Research Design}

This research employed multi-method measures to gather both quantitative and qualitative inputs for identifying the students' and teachers' need in developing the technical-based module on learning the Malay language vocabulary. The rationales for quantitative method are sufficient by themselves to capture the dynamic and individualized teaching and learning style of the teachers and students.

The following list summarizes the steps that were used to carry out this research. Following this list is a more in-depth discussion of each of the steps:

i. Literature search

ii. Participant identification

iii. Need analysis (survey and quiz)

\section{Participants}

This research involved thirty nine (39) vocational teachers who are teaching Malay language, from vocational colleges in Malaysia and also involved 106 students who are in Year One (Sijil Vokasional). The participants for both survey and quiz were selected through the convenience sampling method.

\section{Instrumentation}

For the purpose of data collection, this study employed two methods namely the survey method and vocabulary quiz.

\section{Survey}

The survey approach was used to gather both quantitative and qualitative data. The survey questionnaire were distributed to the participants by mail and post. In the beginning of the questionnaire form, participants were notified on the importance of their input to the study 
and those who are willing to participate would proceed to answer the questions. The survey questionnaire was developed based on the questionnaire developed by Norashidah (2019). Generally, the survey contained questions on demographic information, the requirements of teaching module, and module design. Most questions were close-ended type. One openended question was also included to elicit respondents 'qualitative inputs on the designing aspect of the module.

\section{Quiz}

The other primary technique to perform the needs analysis was by conducting vocabulary quiz / test to students. The participants of this study consisted of 106 students from two college vocational in Northern and Southern states in the country. The test questions were built using 20 vocabularies to construct sentences. The quiz method was helpful for needs analysis since it has the potential to elicit rich, thick descriptions.

\section{Data Analysis}

The collected quantitative data from the survey were organized and analyzed using the statistical software, SPSS. Specifically, the data analysis of the findings include descriptive statistics and frequency analysis for all variables in the study.

The qualitative data from the open-ended question in the survey were organized and analyzed by using a free version of computer-assisted qualitative data analysis (CAQDAS) software, namely the QDA Miner Lite. Thematic analysis was performed to obtain relevant themes suggesting the design requirement of the learning module.

As for the quiz results, data were analyzed statistically using the Microsoft Office Excel software to obtain descriptive information on the distribution of students by the level of scores obtained.

The results obtained from the survey findings and students' quiz scores were integrated manually through side-by-side comparison in the discussion to obtain more comprehensive understanding on the students' performance in Malay vocabulary learning.

\section{Results and Discussion}

\section{Demographic Information}

A total of 39 respondents have answered the survey. Their demographic information are summarized in the following figure and tables.

In terms of gender distribution, Figure 1 show that majority of the respondents were male $(n=24 ; 62 \%)$, while $38 \%$ were female $(n=15)$. With regards to the years of teaching experience, as observed from Table 1, most respondents are considerably having long years of experience in teaching at the vocational colleges. Specifically, majority of the respondents have been teaching at their college between six to 10 years ( $n=18 ; 46.2 \%)$. Meanwhile, 15 of them (38.5\%) have 11 to 15 years of experience, and four others (10.3\%) have been teaching there for 16 to 20 years. Only two respondents (5.1\%) are considerably new teachers with not more than five years of teaching experience in their vocational college. In terms of position held at the colleges, approximately half of the respondents ( $n=22 ; 56.4 \%)$ were general academic teachers without any specific position. On the other hand, 15 of them (35.9\%) were appointed as the Head of Malay Language Subject, while the remaining three of them $(7.7 \%)$ were awarded as Excellent Teachers, or Guru Cemerlang. 


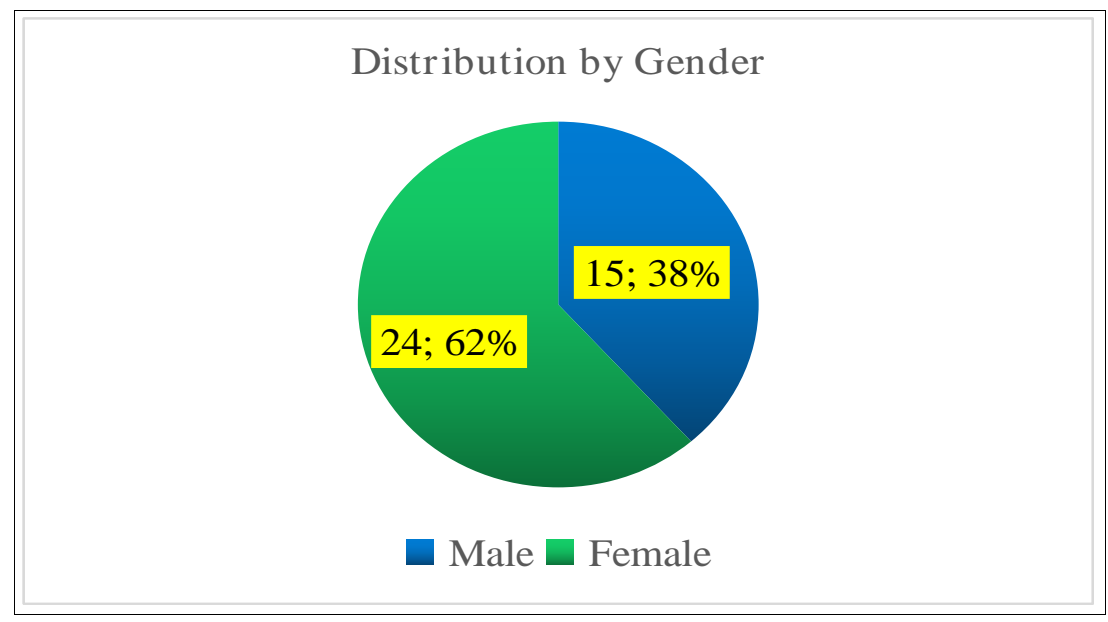

Figure 1. Respondents' distribution by gender

Table 1. Respondents' years of teaching experience in the vocational college

\begin{tabular}{cll}
\hline $\begin{array}{l}\text { Years of teaching experience in } \\
\text { the vocational college }\end{array}$ & Frequency & Percent \\
\hline 0 to 5 years & 2 & 5.1 \\
6 to 10 years & 18 & 46.2 \\
11 to 15 years & 15 & 38.5 \\
16 to 20 years & 4 & 10.3 \\
Total & 39 & 100.0 \\
\hline
\end{tabular}

Table 2. Respondents' distribution by position held in the vocationals college

\begin{tabular}{|l|l|l|}
\hline Position Held & Prequency \\
$\begin{array}{l}\text { Excellent Teacher (Guru } \\
\text { Cemerlang) }\end{array}$ & 3 & 7.7 \\
Head of Malay Language & 14 & 35.9 \\
Subject & 22 & 56.4 \\
General Academic Teacher & 39 & 100.0 \\
\hline Total & &
\end{tabular}

\section{Current Practices and Gaps in Malay Language Teaching for Vocational Students}

The following table and figures illustrate descriptive findings pertaining to respondents' evaluation on the resources and materials used in the teaching and facililation sessions of Malay Language subject at their vocational colleges. Existing gaps in the teaching practices were also discussed.

In terms of the reference types, it is interesting to note from Table 3 that larger group of respondents are utilizing various reference books ( $n=18 ; 46.2 \%)$, compared to textbook $(n=10 ; 25.6 \%)$ in teaching the Malay language subject to the students. Meanwhile, few others are using teachers' modules ( $n=6 ; 15.4 \%)$, own notes $(n=4 ; 10.3 \%)$, and the Eviden SVM reference book ( $n=1 ; 2.6 \%)$. Overall, this finding shows that there are a variety of printed teaching resources and materials for Malay Language subject available for the vocational students. 
Table 3. Types of books/ references used by the vocational students

\begin{tabular}{lll}
\hline $\begin{array}{l}\text { Types of Books/ References Used by } \\
\text { Students }\end{array}$ & Frequency & Percent \\
\hline Malay Language textbook (Form 1) & 10 & 25.6 \\
Eviden SVM reference book & 1 & 2.6 \\
Reference books & 18 & 46.2 \\
Own notes & 4 & 10.3 \\
Teacher's modules & 6 & 15.4 \\
Total & 39 & 100.0 \\
\hline
\end{tabular}

In addition to the above, respondents were also asked on whether or not they are having any issues and problems in delivering the Malay Language lesson in the vocational colleges. As revealed in Figure 2 , majority of them $(n=28 ; 71.8 \%)$ agreed that there are certain issues and problems throughout their teaching and facilitation of the subject to the students.

While the exact reasons to this issue can be many, this finding somehow indicates the existence of gap to be addressed in Malay Language education for vocational students in this country. There are currently lack of literatures that looked specifically into issues and challenges of Malay Language teaching and learning in vocational colleges in Malaysia. However, from a wider perspective, there are several issues and challenges in the delivery of Malay Language education in Malaysian schools. For instance, Zulkifli (2013) listed six major problems in the teaching and learning of Malay language in Malaysian schools, which are teachers' and students' attitudes, examination pressures, syllabus implementation issues, and students' mastery of language skills.

\section{In general, do you face any problem in the teaching and facilitation session of Malay Language?}

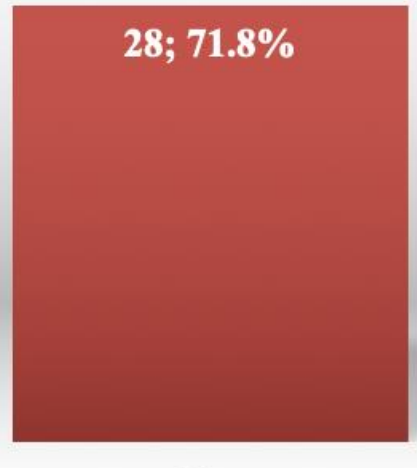

Yes

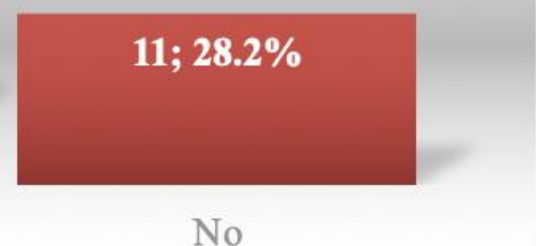

Figure 2. Problems in the teaching and facilitation session of Malay Language

The survey also elicited respondents' evaluation about the uniformity aspect in the usage of references and materials for Malay Language education in the vocational colleges. As shown in Figure 3, almost all respondents $(n=36 ; 92.3 \%)$ agreed that there is currently a lack of uniformity in the use of books or materials by teachers in delivering the Malay Language lessons to the vocational students. This finding could be one of the factors contributing to the previous finding on issues and problems faced by the Malay Language teachers in the vocational colleges. According to Jamaliah (2014), one of the issues faced by lecturers in 
vocational colleges is there is no uniformity in the use of books or materials for the teaching and facilitation of the subject.

\section{Is there uniformity of using books/ materials in the teaching and facilitation process of Malay Language throughout the vocational school/ college?}

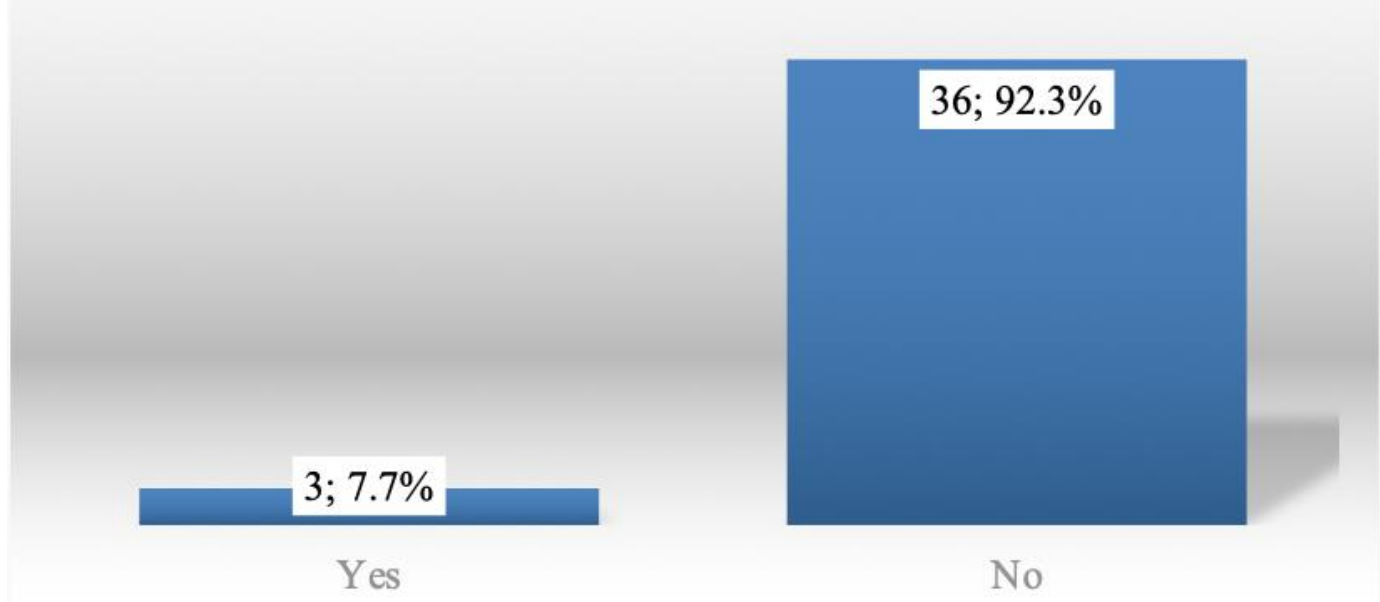

Figure 3. Uniformity in the usage of references

\section{Vocational Students' Performance and Issues in Malay Language Learning}

\section{Survey Findings}

The next section in the survey provides respondents' evaluation on the learning aspect of Malay Language subject among the vocational students. The results obtained from the frequency analysis are shown in Table 4.

From the academic aspect, it was reported by almost all respondents ( $n=37 ; 94.9 \%$ ) that students in the vocational colleges had moderate results for the Malay Language subject. Furthermore, most of them $(n=32 ; 82.1 \%)$ also agreed that the students did not achieve satisfactory level in the subject. One of the plausible reason contributing to this finding could be due to fact that the setting of specific requirement for student entry to vocational colleges is relatively loose: The candidates or graduates must obtain a minimum grade of $D$ only for the Malay Language subject in the Lower Secondary Evaluation, i.e. PT3 assessment (Technical and Vocational Education Division [BPTV] Official Portal, 2019).

Looking from the perspective of issues and challenges, further findings revealed that:

a) approximately $80 \%$ of the respondents agreed that the difficulty in vocabulary learning may cause the students to face problems in learning Malay Language

b) only few respondents stated that the students are highly motivated in learning Malay Language, especially for the grammatical aspect.

c) majority of the respondents did not find that students are able to make grammatical and meaningful sentences with appropriate vocabulary usage

The above findings are somehow in line with a study by Kamisah et al (2016) who reported on vocabulary problems among technical students in Malaysia. This is due to these students, especially in the engineering field, have little exposure to technical terminology in Malay Language since most technical courses are usually carried out in English, and thus they often face problems in understanding the technical terms (Kamisah et al., 2016). With regards to 
students' motivation, Nagy (2007) also agreed that the process of learning vocabulary is a quite difficult process for students because it affects their level of motivation in language learning.

Table 4. Respondents' evaluation on students

\begin{tabular}{|c|c|c|c|c|}
\hline \# & Items & Yes (\%) & No (\%) & $\begin{array}{l}\text { No } \\
\text { answer }\end{array}$ \\
\hline 1 & $\begin{array}{l}\text { Vocational students had moderate } \\
\text { results for Malay Language subject. }\end{array}$ & 37 (94.9\%) & $2(5.1 \%)$ & - \\
\hline 2 & $\begin{array}{l}\text { The level of students' achievement for } \\
\text { Malay Language subject in the } \\
\text { vocational college is satisfactory. }\end{array}$ & 7 (17.9\%) & 32 (82.1\%) & - \\
\hline 3 & $\begin{array}{l}\text { Is the learning process of vocabulary } \\
\text { difficult that it causes students to face } \\
\text { problems in learning the Malay } \\
\text { Language subject? }\end{array}$ & 33 (84.6\%) & $6(15.4 \%)$ & - \\
\hline 4 & $\begin{array}{l}\text { The level of students' motivation in } \\
\text { learning Malay Language especially for } \\
\text { the grammatical aspect is high. }\end{array}$ & $3(7.7 \%)$ & 35 (89.7\%) & $1(2.6 \%)$ \\
\hline 5 & $\begin{array}{l}\text { In general, students are able to make } \\
\text { grammatical and meaningful sentences } \\
\text { with appropriate vocabulary usage. }\end{array}$ & $8(20.5 \%)$ & $31(79.5 \%)$ & - \\
\hline
\end{tabular}

\section{Quiz Findings}

In addition to the survey, a short quiz was developed containing 20 short questions on Malay Language vocabulary. A total of 106 first-year students from two vocational colleges in Malaysia participated and answered the quiz. The quiz was shown in Appendix A. The quiz required the students to write a sentence based on each given Malay vocabulary term in order to evaluate their understandings on the meaning and usage of the words. The scoring was done based on the SPVM grade scores from the Malaysian Examination Syndicate (LPM). Table 5 shows that 64 out of the total 106 students (60.4\%) had failed in the Malay vocabulary quiz, i.e. obtained less than $35 \%$ marks. 42 students (39.6\%) passed the quiz with at least $50 \%$ marks and none of them achieved the A grade, i.e. $80 \%$ and above marks.

This result concurs with the previous finding reported in Table 4 whereby majority of the respondents agreed that the vocational students are having difficulties to grasp understanding in the vocabulary aspect of Malay language. Thus, based on these findings, it can be said that the level of vocational students' achievement in Malay Language subject is still considerably low, especially in the context of vocabulary and writing. This result also supports the study by Kasim (2004) which reported that writing is a skill that is difficult to teach to students in learning Malay language because it involves the most complex level of literacy and requires high cognition process. From the vocabulary aspect, Azman (2017) 
stated that vocabulary proficiency is regarded as the most difficult language skills to be learned by students in Malaysia.

Table 5: Vocational students' scores in the Malay vocabulary quiz

\begin{tabular}{|c|c|c|c|c|c|c|c|c|c|c|c|c|c|}
\hline \multirow{3}{*}{ Colleges } & \multicolumn{13}{|c|}{ Grade of Scores (Vocational Colleges) } \\
\hline & $\begin{array}{l}10 \\
0-\end{array}$ & $\begin{array}{l}89- \\
80\end{array}$ & $\begin{array}{l}79- \\
70\end{array}$ & $\begin{array}{l}69- \\
65\end{array}$ & $\begin{array}{l}64- \\
60\end{array}$ & $\begin{array}{l}59- \\
55\end{array}$ & $\begin{array}{l}54- \\
50\end{array}$ & $\begin{array}{l}\text { Total } \\
\text { Pass }\end{array}$ & $\begin{array}{l}49- \\
45\end{array}$ & $\begin{array}{l}44 \\
-\end{array}$ & $\begin{array}{l}39- \\
35\end{array}$ & $\begin{array}{l}34- \\
0\end{array}$ & $\begin{array}{l}\text { Total } \\
\text { Fail }\end{array}$ \\
\hline & $\begin{array}{l}90 \\
A\end{array}$ & A- & $B+$ & B & B- & $\mathrm{C}+$ & C & & $D+$ & $\begin{array}{l}40 \\
D\end{array}$ & D- & $E$ & \\
\hline$A$ & & & & 2 & 2 & & 1 & 5 & 1 & 4 & 10 & 39 & 54 \\
\hline B & & 1 & 3 & 7 & 11 & 7 & 8 & 37 & 7 & & 3 & & 10 \\
\hline Total & & 1 & 3 & 9 & 13 & 7 & 9 & 42 & 8 & 4 & 13 & 39 & 64 \\
\hline
\end{tabular}

\section{Requirements for Developing the Malay Vocabulary Learning Module}

Respondents were then asked about the design aspect of the Malay vocabulary learning module. Table 6 shows the frequency analysis based on respondents' preference on six components of the module, which are short notes, reinforcement exercises, language games, collaborative games, assessments, and tests.

Table 6. Respondents' preferences on the components of learning module

\begin{tabular}{llll}
\hline \# & Items & $\begin{array}{l}\text { Frequency } \\
\text { of selection }\end{array}$ & Rank \\
\hline 1 & Short notes & 31 & 3 \\
2 & Reinforcement exercises & 36 & 1 \\
3 & Language games & 35 & 2 \\
4 & Collaborative games & 31 & 3 \\
5 & Assessments & 23 & 4 \\
6 & Tests & 3 & 5 \\
\hline
\end{tabular}

As observed, the list of module components according to the ranking of preferences are:

\section{Reinforcement exercises}

Reinforcement learning exercises appears to be mostly preferred by respondents to be integrated in the module. This suggests the importance of learning reinforcement aspect in the delivery of Malay Language education in vocational colleges. As stated by Uddin et al. (2017), reinforcement is one of the key factors affecting student learning during classroom activities in which it refers to the methods used by teachers to maintain their attention towards classroom activities as well as to motivate them towards learning.

\section{Language games}

The second most preferred component in the Malay Language learning module is language games. Thus, it is safe to infer that the vocational teachers in this study emphasized on interactivity and active learning elements in Malay language teaching and learning. Gunter et al. (2016) was in agreement that language learning with game-like and interactive elements offer learners opportunities to develop skills that are transferable to other contexts, either in classroom or other real world social practices. 


\section{Short notes and collaborative games}

Meanwhile, short notes and collaborative games also appear to equally preferred by majority of the respondents. Short notes can be in terms of text messages and audio-based content, while collaborative language games may be used in the forms of online discussion and social media applications. Both components offer more flexible and active language learning process which especially suits the nature of 21st century learning and on-the-go students.

\section{Assessments and tests}

On the other hand, the assessment-related aspect was least preferred by the respondents. As the finding shows, only few respondents selected assessment and test components to be part of the learning module. Gardner and Galanouli (2016) argued that the formation of teachers' perceptions towards assessment is subject to a complex combination of their internal beliefs, the intentions and purposes of the assessment process, as well as their or others' interpretations and behaviours.

With regards to the content aspect, Figure 3 illustrates that almost all respondents agreed that language skills should be incorporate in the Malay Language learning module. Furthermore, as Figure 4 indicates, more than $90 \%$ of total respondents agreed that the module design should be integrated with the syllabus of Malay Language subject as specified in the Standard Curriculum of Vocational College (KSKV).

\section{The design of learning module must involve language skills.}

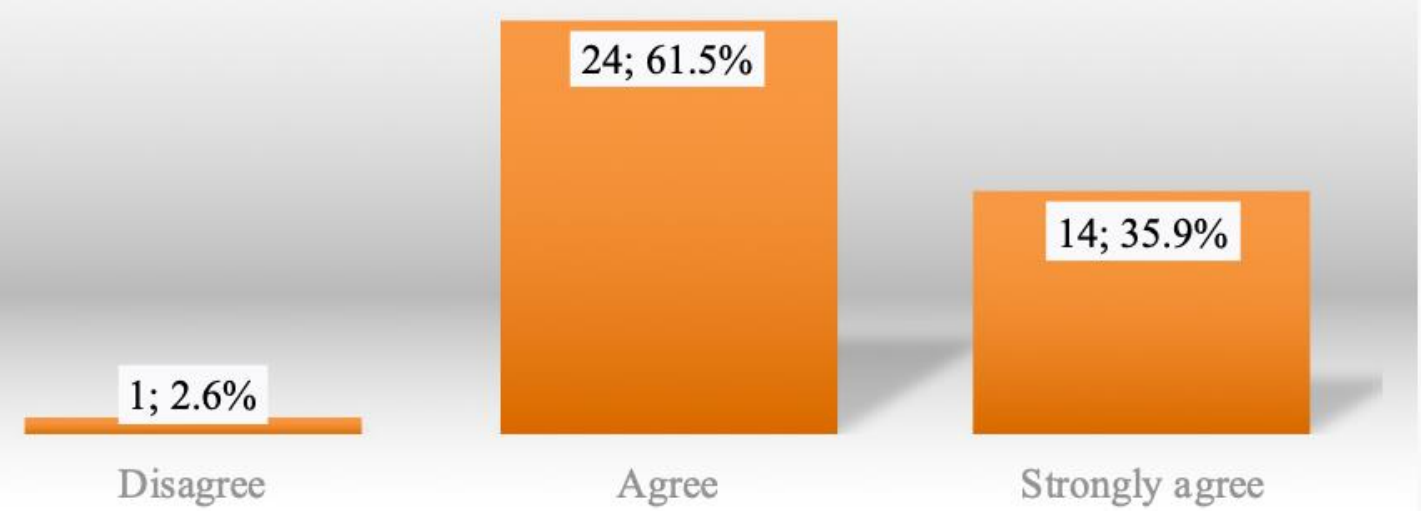

Figure 3. The need of language skills in Malay language learning module 


\section{The design needs to be integrated with the syllabus of Malay Language based on the KSKV}

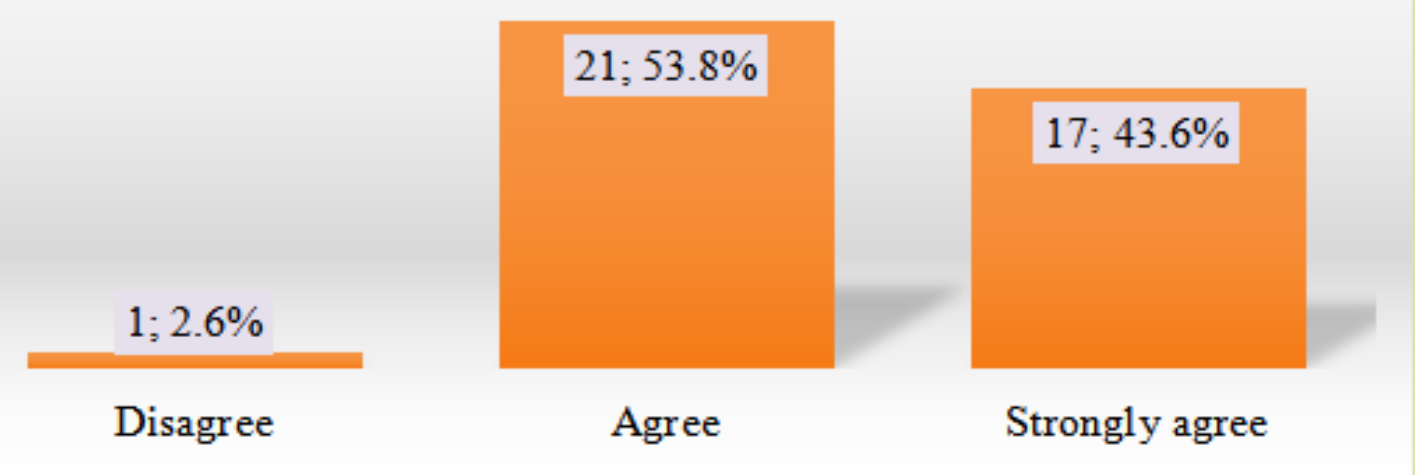

Figure 4. The need for integrating Malay Language syllabus based on KSKV

In addition to the above, respondents also mentioned several suggestions related to the designing of Malay Language learning module. Table 7 shows some examples of respondents' suggestions on how the design of Malay language module can be enhanced. As for the needs analysis of the Malay vocabulary module, the most important aspects arised from the suggestions are:

a. Interactivity :the module needs to include interactive elements, such as language games.

b. Textbooks and references these are the important sources in the teaching and facilitation of Malay Language subject.

c. Uniformity of content :the module content needs to be standardized and consistent, in line with the vocational syllabus.

d. Importance of module :majority of respondents agreed that the Malay Language module is beneficial and thus its development should be further enhanced. 
Table 7. Respondents' suggestions on the module design

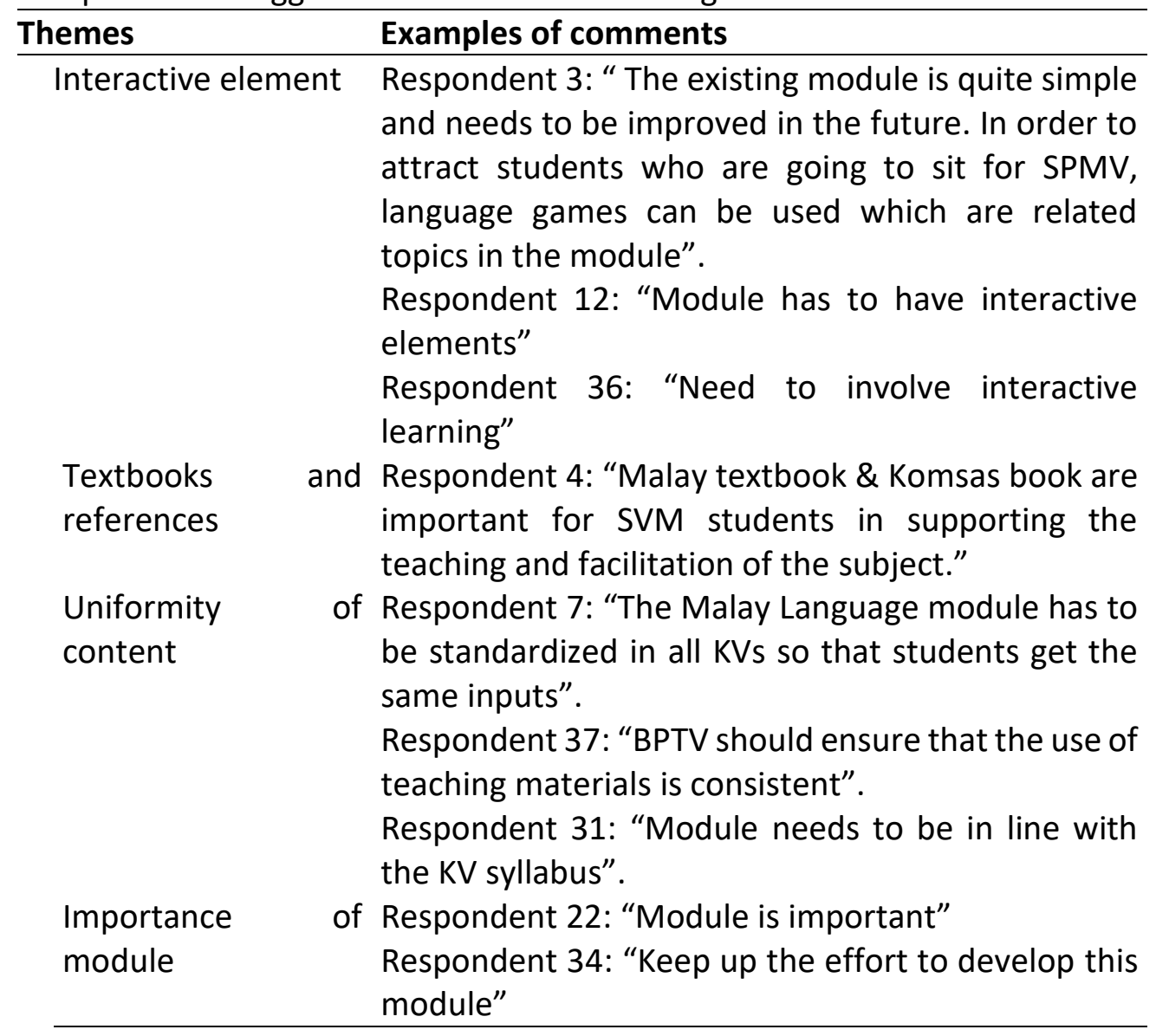

\section{Conclusion}

In conclusion, this study has highlighted the following main findings regarding current teaching and learning practices as well as existing gaps in the delivery of Malay language education for vocational students:

1. Various teaching resources and materials for Malay Language subject are available for the vocational students. However, there is a lack of uniformity in the teachers' use such reference materials.

2. The Malay language teachers in vocational colleges are facing several issues and challenges in delivery the lesson. Other than the reference issues, other problems are related to students, such as their difficulties in vocabulary learning, low motivation in learning grammatical aspect, and lack of understanding on the usage and writing skills for vocabulary aspects.

3. In addition, the analysis of the quiz results also showed that many vocational students still perform poorly in the Malay Language subject.

Therefore, the needs analysis identified that the existing teaching and learning approaches of Malay Language subject in vocational colleges still needs to be improved in order to enhance students' language abilities, especially for writing and vocabulary aspects.

As for the design requirement, findings obtained in this study also provide several recommendations on the needs analysis of the Kadimel module as a learning tool for Malay Language vocabulary learning which are also beneficial for similar studies in the future. The 
following elements can be incorporated for developing the Malay vocabulary learning module that is tailored to the needs of vocational students:

1. learning reinforcement

2. Interactive and collaborative learning

3. Simple, flexible, and effective content

4. Uniformity of references and content

It is also suggested that the design of Malay Language module for vocational students need to be restructured to give more emphasis towards the language practicality in the technical setting of vocational education. Technical and Vocational (TVET) institutions and learning providers in this country can consider implementing some useful educational technology strategies, such as mobile learning applications, in order to effectively support students with the language skills they need, not only for their academic achievement but also for their career prospect.

Despite the above, the study findings should also be considered in the light of several limitations. First, this study only explored the needs analysis involving Malay Language teachers' from two vocational colleges only. Thus, the findings cannot be generalized to represent the whole population of vocational teachers in Malaysia. Secondly, this study did not investigate the aspect from the qualitative perspective, such as through interviews, which may enrich the data obtained. Finally, the perspective of other TVET stakeholders, such as students and administrative staff, still remain unexplored in this study. As Malaysian studies involving the Malay language learning in TVET setting are scarce in number, it is highly recommended that further investigation be conducted to examine the above aspects involving TVET schools and colleges throughout the country.

\section{References}

Abd. Manan, F., Mahamod, Z., \& Embi, M. A. (2010). Kerangka pembangunan dan penilaian modul belajar cara belajar Bahasa Melayu pelajar asing institusi pengajian tinggi. Asean Journal of Teaching and Learning in Higher Education, 2(2), 64-76.

Alias, N., Abdul Rahman, M. N., \& Siraj, S. (2013). Homeschooling bagi kanak-kanak orang asli: Pendekatan fuzzy delphi. Paper presented at the International Seminar Teaching Excellence And Innovation, 25 December, 2013. Garut, Indonesia.

Amiruddin, A. Z., Hassan, A. T., Rahman, A. A., Abdul Rahman, N., \& Abu Bakar, M. S. (2014). Penggunaan aplikasi atas talian dalam proses pengajaran dan pembelajaran bahasa ketiga: pengenalan kepada quizlet. com. In Prosiding Seminar Antarabangsa Kelestarian Insan 2014 (INSAN2014) Batu Pahat, Johor, 9 - 10 April 2014

Azman, W. A. A (2017). The effects of multimedia and modality principles on vocabulary learning among form four students (Doctoral dissertation, Universiti Sains Malaysia).

Clayton, T. (2006). Language education policies in Southeast Asia. Encyclopedia of Language \& Linguistics (Second Edition).

Faridah, M. J., Norlia, A. A., Widad, O., Hairul, N. I., \& Zainudin, M. I. (2014). Amalan Pengajaran Kemahiran Abad Ke 21 Di Kolej Vokasional Sungai Petani 1, Kedah Darul Aman, Malaysia. In Dalam The 8th International Conference on Indonesia-Malaysia Relations, Pekanbaru (Vol. 23, p. 25).

Gardner, R. C. (1985). Social psychology and second language learning: The role of attitudes and motivation. London : Edward Arnold Publishers. 
Gardner, J., \& Galanouli, D. (2016). Teachers' perceptions of assessment. The SAGE Handbook of Curriculum, Pedagogy, and Assessment, 2, 710-724.

Gunter, G. A., Campbell, L. O., Braga, J., Racilan, M., \& Souza, V. V. S. (2016). Language learning apps or games: an investigation utilizing the RETAIN model. Revista Brasileira de Linguística Aplicada, 16(2), 209-235.

Ibrahim, N. (2015). Kesan modul pemulihan intensif dan berterusan terhadap kemahiran membaca dan menulis Jawi dalam kalangan murid sekolah rendah (Doctoral dissertation, Universiti Sains Malaysia).

Jamian, A. R. (2016). Permasalahan kemahiran membaca dan menulis Bahasa Melayu muridmurid sekolah rendah di luar bandar. Jurnal Pendidikan Bahasa Melayu, 1(1), 1-12.

Jamaludin, J. (2014). Kesediaan guru kolej vokasional dalam pengajaran amali Teknologi Elektronik di negeri Pahang. Tesis Sarjana. Universiti Tun Hussein Onn.

Karim, N. S. (2004) Bahasa Melayu sedekad lalu / Nik Safiah Karim. DBP, Kuala Lumpur. ISBN 9789836281210

Kamaruzaman, N. H. (2016). Bahasa Melayu gagal, Bahasa Inggeris Lemah, MyMetro. Retrieved from https://www.hmetro.com.my/node/118888

Kilickaya, F., \& Krajka, J. (2010). Teacher's technology use in vocabulary teaching. Academic Exchange Quarterly, 14, 81-86.

Kurzweil. (2012). How to reinforce learning while you sleep. Retrieved from https://www.kurzweilai.net/how-to-reinforce-learning-while-you-sleep

Lai, L. C. (2017). Bab 1: Pengenalan. Retrieved from studentsrepo.um.edu.my > Fail_4

Loh, P. W., \& Ikhsan, Z. (2019). Meningkatkan penguasaan kemahiran menulis ayat mudah dengan pakej peranti SBK. In e-Prosiding Persidangan Antarabangsa Sains Sosial dan Kemanusiaan, Kolej Universiti Islam Antarabangsa Selangor, 24-25 April 2019.

Mansor, A. (2018). Bahasa Melayu penting untuk penguasaan STEM. Retrieved from https://www.pendidik.com.my/2018/04/01/bahasa-melayu-penting-untuk-penguasaanstem/

Ministry of Education Malaysia. (2012). Draf Dokumen Standard Kurikulum, Kolej Vokasional, KPM: Bahasa Melayu (Modul 1). Retrieved from http://www.geocities.ws/jppkvshas/DSKKV\%20Sem\%201\%202015.doc

Ministry of Education Malaysia [MOE]. (2014). Dasar Memartabatkan Bahasa Malaysia Memperkukuh Bahasa Inggeris (MBMMBI). Retrieved from

https://www.moe.gov.my/dasar/1198-dasar-memartabatkan-bahasa-malaysiamemperkukuh-bahasa-inggeris-mbmmbi/file.

Ministry of Education Malaysia [MOE]. (2015). Kurikulum Bersepadu Sekolah Menengah: Sukatan Pelajaran Bahasa Melayu. Retrieved from http://www.stsimon.edu.my/mn/wpcontent/uploads/2015/05/Sukatan-Pelajaran-Bahasa-Melayu-KBSM.pdf.

Yusof, M. S., Zainuddin, D. S., \& Hamdan, A. A. (2017). Teachers' experience in curriculum implementation: An investigation on English Language teaching in vocational colleges in Malaysia. Sains Humanika, 9(4-2).

Mahamod, Z., Lasan, C., \& Yusoff, N. M. R. N. (2009). Pengajaran dan pembelajaran bahasa Melayu di institusi pendidikan tinggi swasta di negeri Sarawak. Asean Journal of Teaching and Learning in Higher Education (AJTLHE), 1(1), 8-25.

MyGovernment. (2019). Maklumat Malaysia: Bahasa Rasmi. Retrieved from https://www.malaysia.gov.my/portal/content/30118

Nagy, W. (2007). Metalinguistic awareness and the vocabulary-comprehension connection. Vocabulary acquisition: Implications for reading comprehension, 52-77. 
Nurmukhamedov, U. (2016). The contribution of collocation tools to collocation correction in second language writing. International Journal of Lexicography, 4(8), 1-29.

Omar, Z. (2014). Pendekatan konstruktif dalam inovasi pengajaran dan pembelajaran Bahasa Melayu di Kolej Vokasional (unpublished master's thesis). Universiti Tun Hussein Onn Malaysia.

Osman, Z. (2013). Pembangunan modul pengajaran Bahasa Melayu secara bersepadu/ (Doctoral dissertation, University of Malaya).

Osman, J., Mohamad, J. B., Ahmad, A. N., \& Razali, J. R. (2018). Strategi Pengajaran Dan Pembelajaran Bahasa Melayu Dalam Kalangan Pelajar Antarabangsa Di Universiti Malaysia Pahang. PENDETA: Journal of Malay Language, Education and Literature, 9, 6179

Quizlet. (2014). About Quizlet. Retrieved from http://quizlet.com/mission

Ramli, Z., Sarudin, A., \& Mohamed Redzwan, H.F. (2017). Upaya Bahasa Melayu sebagai bahasa ilmu di universiti awam di Malaysia: Pengalaman, realiti dan harapan. In Simposium Internasional Upaya Bahasa Melayu sebagai Bahasa Pemersatu.

Rashid, AB. R. Abdul Rahman, S. B., \& Yunus, K. (2017). Reforms in the policy of English language teaching in Malaysia. Policy Futures in Education, 15(1), 100-112.

Sariyan, A. (2006). Pengajaran bahasa Melayu kepada penutur asing: Matlamat dan Pertimbangan Strategi. Jurnal Persatuan Linguistik, 7, 1-15.

Shanmugam, A., Guat, T.M., \& Nadarajan, S.V. (2015). Analisis penggunaan kosa kata Bahasa Melayu Tahun 3 dengan perisian Range. Jurnal Penyelidikan IPG KBL, 12, 1-17

Uddin, M. R., Hena, S., \& Shanil, A. H. (2017). Influence Of Reinforcement In English Language Learning at Primary Level of Education in Bangladesh. BELTA Journal, 1(1), 85.

Wahab, N. A. (2019). Analisis keperluan pembinaan dan kebolehgunaan modul pengajaran PaTRa bagi topik transformasi isometri. Retrieved from https://docs.google.com/forms/d/e/1FAlpQLScM5Wwilmk7wQvmoLEyGwyNqQYIIGTx6H9zt8rccF_SjBWIQ/viewform

Zakaria, K., \& Abdullah, T. (2014). Mengajar bahasa melayu kepada penutur asing dan cabarannya: pengalaman di Universiti Malaysia Kelantan, Malaysia. In: Professional Development in Education (PDE 2014) Teaching and Learning in The 21st Century : Aspirations and Challenges, 11 - 12 June 2014, Park Hotel, Bandung, Indonesia. 